\title{
Strategy Perception and Implementation on Less \\ Developed Business Ecosystems Micro and Small \\ Enterprises: The Service Sector of Eastern Macedonia and Thrace
}

\author{
Charis Vlados \\ Department of Economics, Democritus University of Thrace \\ PO Box 69100, Panepistimioupoli, Komotini, Greece \\ Tel: 30-253-103-9824Ｅ-mail: vlad.coop@gmail.com \\ Dimos Chatzinikolaou (Corresponding author) \\ Department of Economics, Democritus University of Thrace \\ PO Box 69100, Panepistimioupoli, Komotini, Greece
}

Tel: 30-253-103-9824Ｅ-mail: dimos.chatzinikolaou@gmail.com

Received: July 1, 2019 Accepted: July 24, 2019 Published: July 29, 2019

doi:10.5296/bms.v10i2.15008ＵRL: https://doi.org/10.5296/bms.v10i2.15008

\begin{abstract}
This article aims to find out how micro and small enterprises on a less developed regional business ecosystem perceive and implement some of the fundamental dimensions of business strategy. We analyze 16 critical strategic concepts and construct a strategy perception and implementation index consisting of 16 corresponding queries. We then present the findings of field research conducted in micro and small enterprises in the service sector of Eastern Macedonia and Thrace region in Greece. The results of the strategy perception an implementation index suggest that the "physiologies" of these firms are adjacent to each other and, as expected, these firms record similar scores and share common attributes. These results also point to an explicit - although not strong - tendency of these firms to transform their strategic perception and implementation into more systematic methodologies that seem to approach the benchmark set by the relevant literature. However, a long distance still exists
\end{abstract}


between the actual perception and implementation of these firms and the standards set by the corresponding literature on the subject.

Keywords: Small business strategy, Strategic management, Less developed business ecosystems, Strategy perception and implementation index, Eastern Macedonia and Thrace, Stra.Tech.Man approach

\section{Locating the Research Question and Methodology}

This study aims to distinguish the extent to which micro and small enterprises in less developed business ecosystems are utilizing some of the fundamental theoretical dimensions of strategy design and implementation, as expressed in the relevant literature on the subject.

Business strategy is the far-reaching direction of an organization to make the most of its inherent virtues by avoiding exposure to its weaknesses within the ever-changing external environment (Reyes Avila \& Preiss, 2015; Vlados, 2019; Vlados \& Chatzinikolaou, 2019b). Therefore, business strategy is a dynamical matching game between the evolving internal and external business environment, in a way that manages to make the organization reach where it wants (Gandellini, Pezzi, \& Venanzi, 2012; Ismail \& Kuivalainen, 2015). However, the ambition to develop and implement an integrated strategy is a complex and demanding task for all the organizations involved and concerned.

In this context, this article aims to ask how business strategy unfolds in less developed business ecosystems. Concerning the ecosystem concept, Moore (1993) argues that a business ecosystem, like its biological counterpart, moves gradually from a random collection of elements to a more structured community. A business ecosystem is an economic community supported by a foundation of interacting organizations and individuals. Interdependence and symbiotic relationships are attributes that exist in business ecosystems inherently (Fragidis, Koumpis, \& Tarabanis, 2007). Moreover, those companies holding leadership roles (the "keystone species" according to Iansiti \& Levien, 2004) may change over time, but the community attributes value to the function of ecosystem leader because it enables members to move toward shared visions, align their investments, and find mutually supportive roles (Moore, 1997). Businesses must continuously adapt and evolve to flourish in their ecosystem. This adaptation requires the organization to engage in an ongoing dialogue with its environment and with others with which it shares this environment (Marín, Stalker, \& Mehandjiev, 2007).

When the firms living in a business ecosystem are less competitive, then the business ecosystem is comparatively weaker or less developed. According to Harrison et al. (2018), a lack of a matching platform to make the connection between investors and entrepreneurs results in a poorly developed entrepreneurial ecosystem. Spigel and Harrison (2018) argue that less-developed ecosystems may see an outflow of resources as entrepreneurs realize they must leave the region to grow their firm successfully because of a lack of available investment capital, demands from investors that they relocate, or the need to move to broader labor markets to tap the talent they need. Moore (2015) argues that the ecosystem as a whole 
must draw deeply from advances in science and engineering; otherwise, the whole community stagnates. According to Brown and Mason (2017), the entrepreneurial ability and good strategy of firms to "sense and seize" new growth opportunities resonate with the premise underlying the entrepreneurial ecosystems.

Therefore, the way the socioeconomic organizations in a business ecosystem articulate their strategy is crucial. However, how do micro and small enterprises seem to shape and implement their strategy? The literature identifies a divergence between the theory and the practice of strategic management in small enterprises. According to Analoui \& Karami (2003), while the volume of literature on strategic management in large organizations is extensive, the literature on SMEs is rather limited. They argue that while some writers have concluded that small firms do not commonly practice strategic management, some studies have found a positive relationship between strategic planning and performance in these companies. In a similar vein, Mazzarol (2003) argues that strategic management theory appears to apply to small firms experiencing growth and change. However, due to the relative immaturity of most small firms, their "natural" state is one of learning by doing and inventing their future on almost a daily basis. Consequently, Kraus, Reiche, and Reschke (2008) suggest that SMEs usually maintain a lower level of resources, have more limited access to human, financial, and customer capital, and lack a well-developed administration. Thus, the application of formal planning instruments is often missing, especially up to a specific "critical size."

This article synthesizes upon the concepts of less developed business ecosystems and small business strategic planning and raises the following question: How do the locally established micro and small enterprises of a less developed regional business ecosystem understand and implement their strategy?

Concerning the structure and methodology, this study will initially present 16 central dimensions of strategy making according to the strategic management literature. These 16 strategic dimensions lead to the construction of 16 corresponding queries and create a composite index of strategic perception and implementation. The study then assigns a value to this index by accommodating the results of field research conducted in micro and small enterprises of the service sector in the region of Eastern Macedonia and Thrace. Finally, we discuss the findings and highlight the prospects for future research.

\section{Literature Review and Construction of the Questionnaire}

Many analysts continue to approach and enrich the theory of organizational strategy perception and implementation. In this context, we present 16 strategic dimensions by utilizing significant contributions from international literature. After the brief examination of each point, we produce a question that is part of an integrated questionnaire used by a field survey. With this in mind, we create a composite strategy perception and implementation index, consisting of 16 independent strategic dimensions (Figure 1). We consider these dimensions in this study as equivalent. 


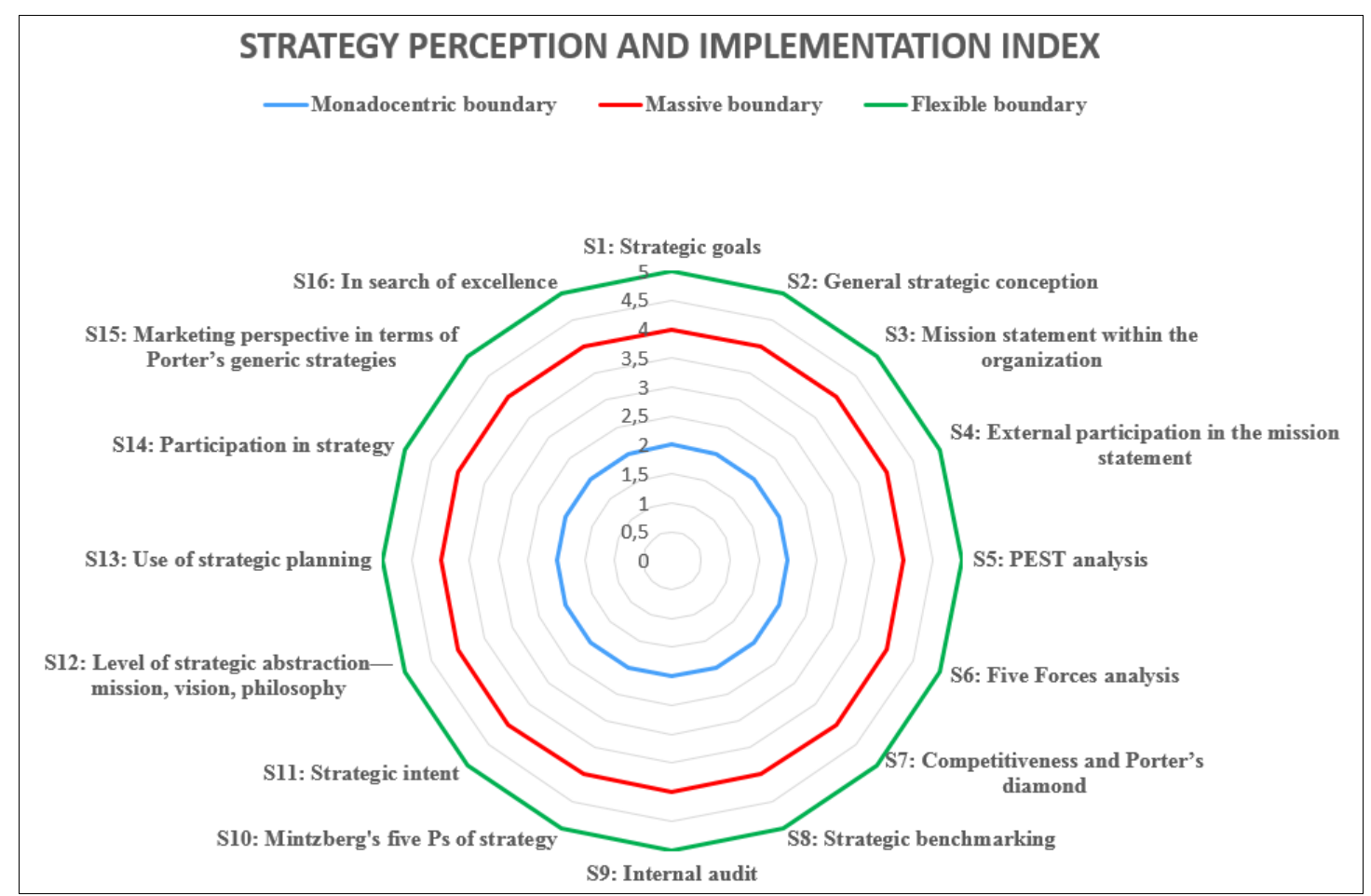

Figure 1 . The strategy perception and implementation index. The "monadocentric-massive-flexible" business boundaries.

According to Vlados (2004; Vlados \& Chatzinikolaou, 2019a), in less developed socioeconomic systems (such as Greece) a peculiar type of entrepreneurship continues to survive and prevail, the "monadocentric" type. The "monadocentric" firms rely heavily on their strategic intuition, make sporadic technological choices, and use management techniques based solely on their practical experience. Therefore, they are only capable of building and sustaining a less competitive and adaptive "triangle" of strategy, technology, and management (Stra.Tech.Man). In particular, the author suggests the existence of an idiosyncratic "Stra.Tech.Man physiology" that characterizes each socioeconomic organization according to three fundamental spheres of questions.

* The strategy corresponds to "where is the organization today, where does it want to go, and why?"

* Technology corresponds to "how does the organization draw, create, reproduce, and disseminate the available knowledge, and why?"

* Management corresponds to "how does the organization manage its available resources, and why?"

Depending on the degree of development of the Stra.Tech.Man triangle, there are "monadocentric" or "massive" or "flexible" types of organizations. Overall, according to the typology of Vlados $\left(\mathrm{B} \lambda \alpha \dot{\delta} \delta \sigma_{\zeta}, 2006\right)$, these three types of firms maintain the following characteristics: 
* The monadocentric "physiology" of entrepreneurship does not apply at all distinct strategic planning procedures, chooses its technology sporadically, and relies heavily on the practical experience.

* A massive "physiology" of entrepreneurship tends to stick to a rigid formalism and inelastic strategic thinking, to a linear and repetitive technological application, while its management follows an advanced specialization and strict quantitative methods of programming and organizing.

* A flexible "physiology" of entrepreneurship, which is scarce in the productive system in Greece, follows an evolutionary perception of strategy, participatory decision-making systems, and networking abilities to assimilate technology and expertise.

The index of strategy perception and implementation, which distinguishes between these types of firms, takes into account the following 16 critical strategic dimensions:

I. Strategic goals: According to Spyropoulou et al. (2018), managers should be concerned about any failures to achieve strategic goals as they significantly reduce financial performance. Mia, Sands, and Iselin (2008) suggest that organizations should closely align their strategic goals with their performance reporting measures and give emphasis to their performance reporting system. According to Houston et al. (2010), the goal-setting processes in firms are dynamic and trigger intra-firm conflict. Therefore, the strategic analyst should be able to capture the potential facilitating and debilitating effects of each goal-setting process on a firm's goal-directed pursuits.

These theoretical arguments lead to the following question: "Is there a principal strategic goal, and how does the goal-setting process take place in your organization? At what speed does the organization adapt to changes while maintaining a long-term strategic rationale?"

II. General strategic conception: According to Porter (2000), primitive forms of strategy rely on factor (input) costs, while more advanced forms involve competing based on differentiated products and services and, ultimately, on unique competitive positioning versus rivals. According to González-Dávila et al. (2014), SMEs fall within four strategic types, as proposed by Miles and Snow (1978). The "defender" concentrates on a narrow and limited product-market area; the "prospector" always seeks new market opportunities; the "analyzer" is the adaptive firm that is a symbiosis of the previous two; the "reactor" is the firm that lacks a clear and consistent strategy.

These theoretical arguments lead to the following question: "What is the general strategic conception of your organization? Is your strategy 'flexible' and systematically oriented towards change?"

III. Mission statement within the organization: According to Karami and Taghi Alavi (2009), the involvement of employees, as well as CEOs/business owner-managers in developing the mission statement, improves the performance of the company. In a 
similar direction, Hong et al. (2010) suggest that corporate mission and its embedded policies contribute to better corporate performance. Furthermore, according to Hamel and Prahalad (1994), when a company's mission is undifferentiated from that of its competitors, employees may be less than inspired.

These theoretical arguments lead to the following question: "If there is a written mission statement in your company, then who is involved in developing this mission statement? To what extent do all the human resources of the organization participate in developing the mission?"

IV. External participation in the mission statement: Baetz and Bart (1996) argue that all relevant stakeholders should be involved in creating the mission statement, including customers, who are the most frequently mentioned stakeholders of a mission statement. Bartkus and Glassman (2008) posit that mission statements are both internal policies and guides to direct behaviors and decision making externally directed messages. According to Fitzgerald and Cunningham (2016), mission statements must be clear articulations to internal and external stakeholders of the long-term intent of an organization.

These theoretical arguments lead to the following question: "To what extent has your business mission recognized and expressed your business goals based on regular contact and collaboration with your customers, partners, suppliers, and the wider society?"

V. PEST analysis: Sammut-Bonnici, Galea, and Cooper (2015) argue that PEST (political, economic, social, and technological) factors help to understand strategic risk and evaluate how business models will have to evolve to adapt to their environment. According to Barkauskas et al. (2015), the PEST qualitative analysis must not exclude factors that have anticipated favorable or unfavorable effects and predicted the influence of macroenvironmental factors on a branch of industry, sector, or company's strategy.

The above theoretical contributions lead to the following question: "To which extent does your business strategy take into account and exploit the evolution of extra-sectoral trends and factors in shaping strategic decisions?"

VI. Five Forces analysis: This framework examines the firm's industrial environment by taking into account the bargaining power of suppliers, the bargaining power of customers, the dynamics of substitute products and services, competitive rivalry, and the threat of new entrants. According to Porter (1980), who introduced this analysis, the combined dynamics of these forces determines the profits an industry can offer. When strong bargaining forces surround the firm, and the organization is incapable of formulating a proper strategy, then these "condemn" the firm in harsh to survive conditions and, therefore, limited growth.

This theoretical argument leads to the following question: "To which extent does your 
organization monitor systematically the dynamics of its direct competitive environment (customers, competitors, potential new competitors, and substitute products, the networks of trade intermediates and partners, and complementary products)?"1

VII. Competitiveness and Porter's diamond: There is no absolute analytical consensus for a well-established model of competitiveness (Balkytė \& Tvaronavičienè, 2010). Regardless of the type of competitiveness - at the national, industrial or firm level-being competitive means that a socioeconomic entity performs, in general, better than its counterpart ones. According to Peneder (2017), competitiveness is the ability of an economic system to develop and, therefore, to achieve high real incomes together with qualitative change. According to Porter (1990), four attributes are leading to an ever more sophisticated source of competitive advantage for a nation. These constitute the "diamond of national advantage" that each nation establishes and operates for its industries. First, the "factor conditions" highlight the nation's position in factors of production, such as skilled labor or infrastructure, necessary to compete in a given industry. Second, the "demand conditions" highlight the nature of home-market demand for the industry's product or service. Third, the "related and supporting industries" highlight the presence or absence in the nation of supplier industries and other related industries that are internationally competitive. Fourth, the factor of "firm strategy, structure, and rivalry" highlights the conditions in the nation governing the how companies are created, organized, and managed, as well as the nature of the domestic rivalry.

These theoretical arguments lead to the following question: "To what extent does your business competitiveness get enhanced from a more sophisticated productive fabric of other organizations, input and output markets, interactions in terms of technology diffusion and assimilation, local external environment, and state-social intervention institutions? Does your business strategy fit into the above-mentioned structural balances at the local operating level?"

VIII. Strategic benchmarking: According to Stapenhurst (2009), in strategic benchmarking, organizations tend to benchmark long-term strategies to find those that seem to result in business success. It typically focuses on areas such as product development, customer services, and core competencies. Watson (2014) argues that benchmarking studies conducted at the strategic or operational level of the organization may compare competitive organizations, internal divisions or processes, industry-wide practices, or general business practices in cross-industry studies.

These theoretical arguments lead to the following question: "To which extent does the articulation of your strategy capture systematically data relating to other "successful"

\footnotetext{
1 At this point, we propose the networks of trade intermediates and partners, and the complementary products, as two additional categories in the "5 Forces Analysis"- towards a "5+2 Forces Analysis."
} 
strategies within and outside the industries in which your company operates?"

IX. Internal audit: According to Burton et al. (2012), internal auditing provides insight and recommendations based on analyses and assessments of data and business processes. According to Prawitt, Smith, and Wood (2009), internal auditing may involve topics such as an organization's governance, risk management and management controls over the effectiveness of operations (including the safeguarding of assets), the reliability of financial and management reporting, and compliance with laws and regulations.

These theoretical arguments lead to the following question: "To what extent does your organization activate mechanisms systematically for monitoring and evaluating its internal business operations and present the findings in the form of regular internal audit reports?"

X. Mintzberg's five Ps of strategy: According to Mintzberg (1987), there are five interrelated definitions to understand strategy. First, strategy as a "plan" that is a consciously intended course of action, a guideline to deal with a situation. Second, a strategy can also be "ploy," a specific maneuver intended to outwit an opponent or competitor. Third, the strategy can also be a "pattern," a pattern in a stream of actions, which signals a consistency in behavior, intended or not. Fourth, a mean of locating an organization into its environment is the strategy as "position," where strategy is the mediating force between the internal and external organizational context. The fifth definition, strategy as "perspective," looks inside the organization, suggesting an ingrained way of perceiving the world. Mintzberg argues that these definitions compete, but perhaps, more importantly, they complement each other.

This theoretical argument leads to the following question: "What is the degree of activating and exploiting the "5 Ps of Strategy" formulated by Mintzberg in your business strategy?"

XI. Strategic intent: According to Hamel and Prahalad (1989), companies that rise to global leadership begin with disproportionate ambitions to their resources and capabilities. The authors call "strategic intent" the obsession of these organization for winning at all levels. Prahalad and Hamel (1990) introduce the "core competence" concept subsequently. To identify competencies that support the strategic intent, a company must ask the following: how long could we dominate our business if we did not control this competency? What future opportunities would we lose without the core competence? Does it provide access to multiple markets? Do customer benefits revolve around it?

These theoretical arguments lead to the following question: "How does your organization adapt to its changing environment? What are its core competencies? How does it envision the future ahead of its competitors by changing the "rules of the game" with its strategic intention?"

XII. Level of strategic abstraction — mission, vision, philosophy: The vision outlines the shape 
of the corporation in the future, sets general goals, and leads the strategy and the mission of the business. The mission outlines the primary purpose of the firm, determines the relationship between the company and other organizations, and sets specific objectives (Alt1ok, 2011; Ingenhoff \& Fuhrer, 2010). The philosophy incorporates organizational values and defines general principles and ethical behavior in the operation of the firms. It determines the nature of the relationships with the stakeholders that the business trades, and defines the style of management (Abdullah, Shahrina, \& Abdul Aziz, 2013; Campbell \& Tawadey, 1990).

These theoretical arguments lead to the following question: "In which of the three complementary dimensions of "vision-mission-philosophy" do you think your organization has higher-level strategic processing?"

XIII. Use of strategic planning: Strategic planning can be an overwhelming challenge to take into account, simultaneously, the developments of technologies and societal trends, the behavior of competitors, customers, and regulators, all within a changing legal, environmental, and financial framework (Eppler \& Platts, 2009). Abdallah and Langley (2014) argue that strategic planning may serve as a means to develop consensus and promote commitment among organization members around strategic orientations. Dibrell, Craig, and Neubaum (2014) correlate strategic planning with "planning flexibility" defining that flexibility as "the ability of a firm to deviate from its formal strategic plan in response to emerging opportunities or threats."

These theoretical arguments lead to the following question: "How does your organization take advantage of its strategic planning in its everyday practice?"

XIV. Participation in strategy: Mantere and Vaara (2008) argue that a lack of participation leads to poorly developed strategies, dissatisfaction among the excluded participants, and consequent difficulties in implementation of the strategy. Ackermann and Eden (2011) suggest that participation in strategy-making results in a greater awareness of what means to be a member of the group and a stronger emotional investment in its membership. Finally, Kaleta and Witek-Crabb (2015) argue that participation in strategy creation and implementation help better accommodate changes in the environment and build up the relational capital of the organization.

These theoretical arguments lead to the following question: "Is the strategic success of the company based on the initiatives by the business owner or by team collaboration and creativity of all the participants?"

XV. Marketing perspective in terms of "Porter's generic strategies": According to Porter (1980), there are three generic strategic approaches to outperforming other firms in an industry. The "cost leadership" strategy requires cost minimization in areas like R\&D, service, sales force, and advertising. The "differentiation" strategy creates something perceived as unique by the industry. The "focus" strategy intends to serve very well a particular buyer or group, a segment of the product line, or a specific market. Porter 
suggests that the firm can successfully pursue more than one approach as its primary objective, though this is rarely possible.

These theoretical arguments lead to the following question: "Which marketing perspective does the company use? Does the company follow the rationale of "selling whatever is sellable" or "the product must cover the customer's and the entire society's immediate and long-term interests" or something different?"

XVI. In search of excellence: According to Peters and Waterman (1982), eight common themes call for specific actions that define the strategic success of a corporation. The "bias for action" is for quick and creative assimilation of environmental change. The "close to the customer" concept understands the customer as the company's partner that ultimately defines the quality. The "autonomy and entrepreneurship" encourages the innovator and the risk-taker. The "productivity through people" sees in the human factor the source of creativity and business success. The "hands-on, value-driven" declares the predominant mission and values of the firm that needs to be flexible. The "stick to the knitting" concept perceives the knowledge of the specific product and its production through the accumulated experience of the business as critical. The "simple form, lean staff" calls for fewer hierarchical levels that can provide fast and efficient communication. The "simultaneous loose-tight properties" declares that firms must exploit both centralization in some processes and widespread decentralization in others.

These theoretical arguments lead to the following question: "To what extent does the company's strategy trigger and make use of the "search of excellence" principles, viewing them as foundations in business operations?"

\section{Methodology: Field of Investigation and Identity of the Research}

We have utilized the above 16 central questions of strategy development and implementation within the strategy perception and implementation index in specific field research. We have conducted a survey in the Greek region of Eastern Macedonia and Thrace in a sample of micro and small enterprises during the spring semester of 2019.

We focus on the region of Eastern Macedonia and Thrace because is one of the thirteen regions of Greece and is one of the least developed regions in Greece and Europe (Boden, 2017). It is a border region (Prokkola, 2019; Varol \& Soylemez, 2019) that combines socioeconomic and demographic problems, which contribute to this region's failure to keep up with developments in other Greek and European regions. Regions such as Eastern Macedonia and Thrace demonstrate high comparative costs (Arieli, 2019; Mayer, Zbaraszewski, Pieńkowski, Gach, \& Gernert, 2019), such as negative economies of scale and higher operating costs for business and living for their residents. According to the most recent data of the Hellenic Statistical Authority (2019), the region recorded the lowest per capita GDP in $2016(€ 11,432)$ compared to the country average which was $€ 16,378$ (the highest GDP per capita was recorded in Attica, €22,204). According to Vlados, Deniozos, and 
Chatzinikolaou (2018), the gross value added in the region of Eastern Macedonia and Thrace for selected industries recorded between 2008 and 2014 a decline of $35.5 \%$.

In this context, as expected, entrepreneurship in less developed regional business ecosystems such as Eastern Macedonia and Thrace faces structural problems, functional deficiencies, and imbalances. In regions with weak entrepreneurial systems, mechanisms formed because of the recognition and necessity for knowledge and innovation-based interactions beyond the market are less apparent (Huggins and Thompson, 2015). According to Asheim, Moodysson, and Tödtling (2011), less urbanized or peripheral regions demonstrate a lack of dynamic firms and knowledge-generating organizations. On the contrary, Fernández-Serrano and Romero (2013) argue that SMEs in highly developed areas tend to be more innovative, more internationalized, and more efficient than in low-income areas. Overall, the majority of analysts on the subject suggest that SMEs in low-income economies tend to have lower entrepreneurial quality.

With this in mind, we have carried out field research at the less developed business ecosystem of Eastern Macedonia and Thrace to find out the current level and growth prospects of these enterprises that are mostly of "monadocentric" type. More specifically, 54 micro and small enterprises in the service sector participated in the field survey. One of the sampling criteria was that businesses would employ up to 50 employees, have their headquarters in the region of Eastern Macedonia and Thrace, and belong to the service sector. The majority of sample firms have as their basis the regional unit of Rodope; they are active in food and beverages services mostly, and employ from one to five employees (Figure 2).

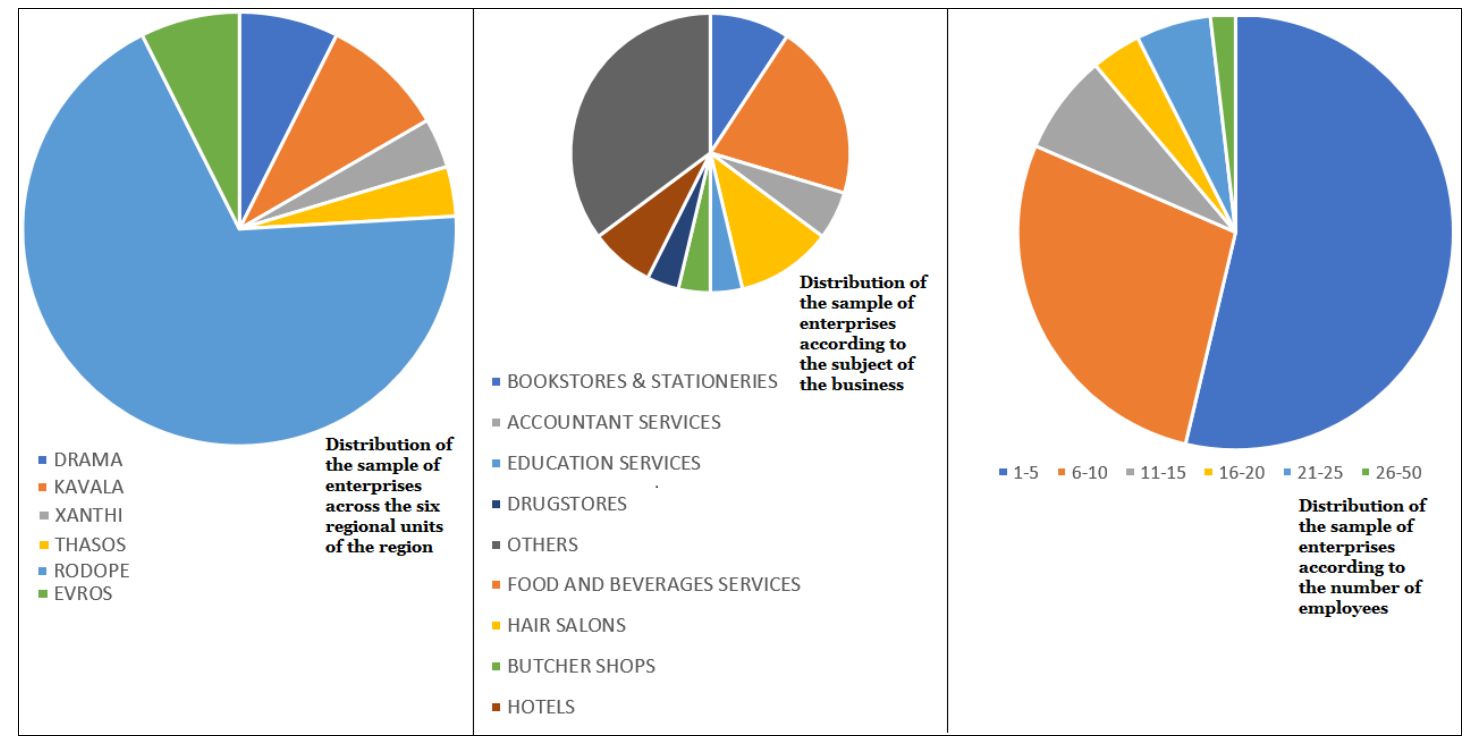

Figure 2. The sample of the 54 firms based on their location, business subject, and the number of employees.

The field research in these 54 firms uses structured questionnaires. It is introductory and qualitative (Shields \& Rangarajan, 2013) since it does not seek to discover and propose a case with full interpretative and predictive ability. The purpose of the research is to make a first 
exploration (Stebbins, 2001) to form more comprehensive case studies with more empirical data in the future (Johnson, 2001; Neergaard \& Ulhøi, 2007).

The survey exploits a questionnaire (see Appendix) divided into 16 strategic questions where respondents respond based on their perception on the subject. The questionnaire uses for each of the 16 queries a Likert-type scale (Burns \& Bush, 2008; Likert, 1932), where respondents have to respond based on the level of agreement or disagreement in a series of statements about the concept of strategy. In this questionnaire, the scale for the 16 queries is from 0 to 5 , where at one end $(0,1$, and 2$)$ the answer points to the "monadocentric" character, at the intermediate score (3 and 4) the answer points to the "massive" character, while in the most advanced stage (5) the answer points to the "flexible" character. Besides, each question sets two scales of responses to see how the trend evolves throughout time: "today" is the first scale, and "in the past" is the other scale. Finally, under every query, the respondents must answer briefly to the question "where would you like to be today instead, and why?"

\section{Field Research Results}

After calculating the average score of all queries, the result is 2.4 in the past and 3.1 today. In addition, all changes to the queries are positive, indicating the desire of these firms to systematize their strategic processes concerning their past, in the directions presented by the literature on the subject. We present below the scores of the 16 strategic questions (Figure 3). ${ }^{2}$

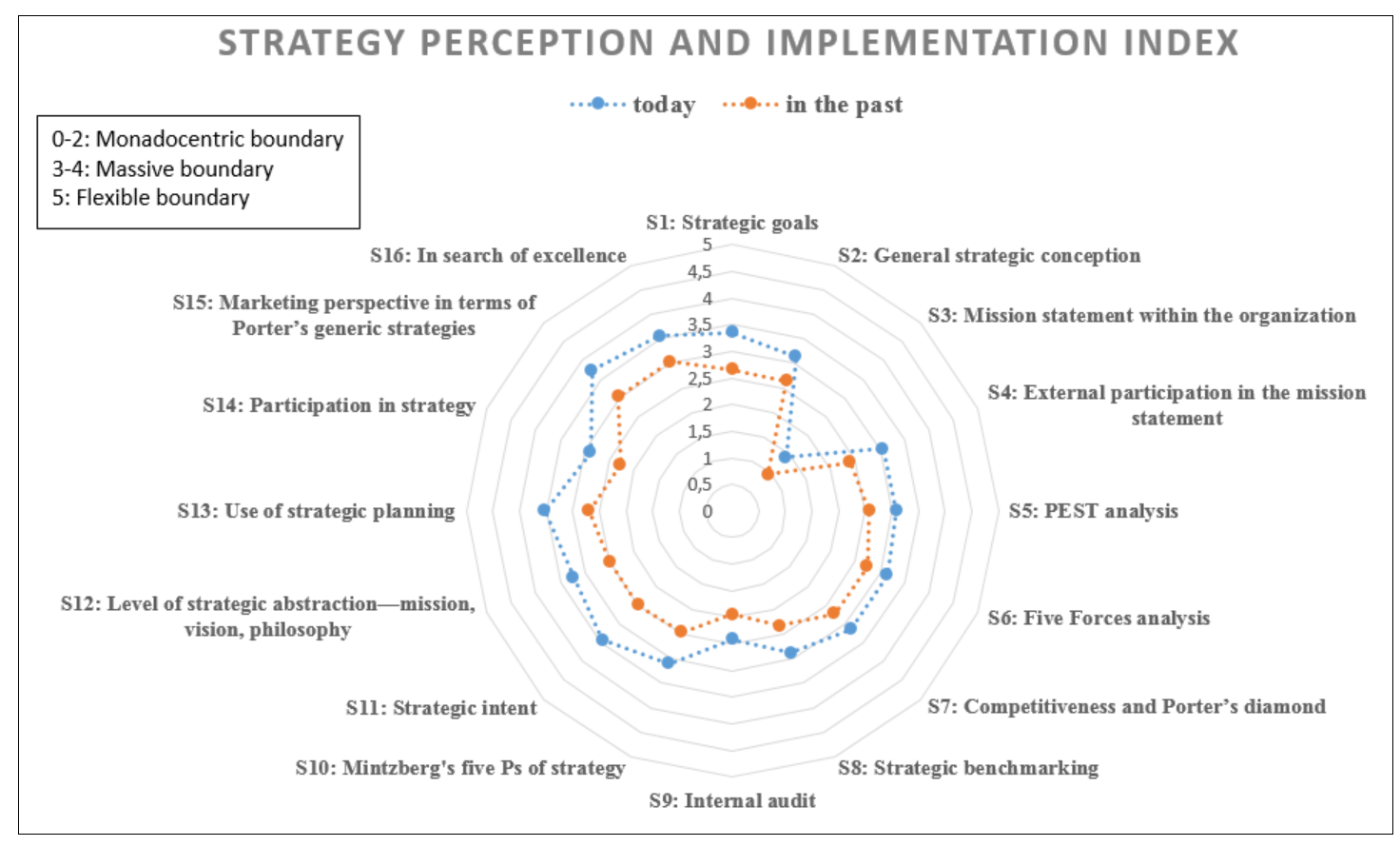

Figure 3. The results of the strategy perception and implementation index in the sample of 54 micro and small enterprises in the service sector of Eastern Macedonia and Thrace.

\footnotetext{
2 The raw transcribed material is available to any interested researcher upon request.
} 
I. The response to the question of having a principal strategic goal is changing by +0.7 points, from 2.65 to 3.35 . This change suggests a gradual expansion and long-term perspective as a strategic goal in strategic analysis, even in small firms. To this end, a firm answers" that "I would like to be instead in 4. I believe that the existence of a long-term plan combined with the flexibility and adaptability to new data is a strategy that leaves much room for growth."

II. The response to the question of whether or not there is a general strategic logic in the organization is changing by +0.48 points, from 2.65 to 3.13 . It seems that these firms want to have a strategy, which they even perceive as systematically articulated. To this end, a firm answers that "The success of my business is due to the plan I have been following all these years, which is based on stability and very good programming."

III. The response to the question of participation in developing the mission statement marks a change of +0.47 points, from 0.96 to 1.43 - the smallest score among the 16 queries. It seems that these small businesses have only recently begun to perceive the contribution of the corporate mission to the performance of an organization. To this end, a company answers that "I think that a more documented and written statement of the company's planning and mission will be necessary over time."

IV. The response to the question of whether the company's mission expresses the business goals based on systematic collaboration with the broader society shows a change of +0.68 points, from 2.39 to 3.07 . The score change suggests a tendency to systematize the development of the corporate mission, especially concerning the business customers interests. To this end, a firm answers as follows: "we take into account the customer's opinion by trying to meet as many needs as we can. In our effort to evolve, in general, we have created a complaint paper for our customers."

$\mathrm{V}$. The response to the question of whether the business strategy takes into account the dynamics of the external environment shows a change of +0.52 points, from 2.74 to 3.15. This trend demonstrates the desire of these firms to adapt to their external environment successfully by recognizing their threats and exploiting their opportunities. A firm answers that "I would like to be more informed about all the above factors so that I know where Greece lies economically, technologically, and politically."

VI. The response to the question of whether the firm collects data concerning its sectoral environment changes by +0.41 points, from 2.74 to 3.15 , which is the smallest change among the 16 questions. It seems that these firms design their strategy by taking into account, most of the time, the bargaining powers surrounding the business. One answer in this direction is that "there are few competitors in the same business subject,

\footnotetext{
3 The data we add belong in the "job notes" category, which is a method of taking notes while the researcher is in the study. These are short notes, concise and in condensed form used by the researcher in later stages of the research.
} 
so there are not many ways to emerge unless you are remarkably good at your job or have low prices that stand out."

VII. Regarding whether a sophisticated competitive environment enhances the firm's competitiveness, there is a change of +0.43 points, from 2.72 to 3.15 . The result shows that there is a tendency to systematize the mechanisms for detecting the dynamics of the environments involved in the organization that leads to an improvement in its production capacities. A firm answers that "I would like to be at 4. This score reflects the rapid and correct assimilation of technology and always environmentally friendly actions."

VIII. To the question of whether the firm articulates strategic benchmarking mechanisms, the score moves from 2.33 in the past to 2.89 today. The result shows that these firms tend to count increasingly on other successful strategies. Answers such as "I do not think is important to compare the strategies of other businesses" are the minority, while responses such as "we get continuous feedback from other successful strategies to improve and modernize our strategic plan" contribute to the overall trend.

IX. In the question of using internal audit and feedback mechanisms, the average in the past is 1.94 points, while at present 2.41 points. This change suggests that the internal audit has previously been more superficial without taking into account all of the business functions. The answers, however, do not fully justify this increase in the average score. The typical answers are as follows: "I do not think that internal audit concerns my business" and another that "I do not need mechanisms for assessing the transformations within the company since I work most of the time by myself."

X. Concerning whether the company uses different concepts in the strategy based on Mintzberg's definitions, the change is +0.64 points, from 2.47 to 3.11 . This substantial change suggests a tendency to increase the activation of different strategic perspectives but without the desired synthesis of Mintzberg's 5Ps. One typical answer by a firm is that "I get some elements of everything, but especially of strategy as a pattern and perspective."

XI. The question whether a firm adjusts its strategy to the environment passively or actively by having as strategic intent to change the "rules of the game" marks the most significant change (+0.94 points), from 2.50 to 3.44 . This change suggests that the majority of these firms do not want only to survive, but they also maintain ambitions that are disproportionate to their size and current core competencies.

XII. Concerning the complementary concepts of vision, mission, and philosophy, the change is +0.74 points, from 2.50 to 3.24 . These scores reveal that the strategic processing of these three fundamental spheres is ever increasing. One typical answer by a firm is that "Based on the strategy I follow, I try to balance them together as much as I can."

XIII. Concerning how the firm uses its strategic planning, the responses give 2.28 points in the 
past and 2.89 at present. The strategic planning for this sample of firms poses a challenge, revealing a tendency for an increasing number of factors contributing to strategic analysis. One typical answer by a firm is that "The organized orientation and the business plan are factors that lead slowly or quickly to success."

XIV. Concerning the question of participation in strategy making, the score moves from 2.28 in the past to 2.89 today. This change suggests that these firms gradually realize that if the initiatives of the business owner are building the strategy solely, then poorly developed strategies can occur. A response that reveals the majority trend that justifies this positive change states that "I would like to have some help from a staff member that, when combined with my views and experience, can lead to strategic success."

$\mathrm{XV}$. The response to the question of marketing perspective marks the highest score since it records 3.04 points in the past while 3.74 points at present. It seems that, in terms of promotion, these firms are trying to both sell at a low price of high quality and diversify their focus on ever-larger segments of the market sufficiently. One answer by a firm is that "I would like to be at 5 . I consider that the contribution to society is a two-way process from which society and business get favored."

XVI. In the question of using the "search of excellence" principles, the average score changes by +0.53 points, from 3.03 to 3.56 . This trend indicates that, despite their size, these firms are adaptable to change by increasing gradually the actions that lead to strategic success. A response that characterizes the majority gives the following response: "As a business, we are trying to adapt to change. As far as customers are concerned, we are very close and, therefore, we are aware of their needs and wants. We base our strategy on simplicity and rapid efficiency."

\section{Conclusions and Limitations}

To emphasize the evolutionary view of socio-economic phenomena, Alfred Marshall (1890) argued that there are no leaps in nature ("natura non facit saltum"). In this sense, there are also no leaps of strategic "physiology" for the business organizations, which are living and evolving entities. After using a strategy perception and implementation index based on 16 critical strategy questions, this study arrives at the following conclusions:

- The necessary conclusion is that the average of the sample of firms is not transforming rapidly through time. The partial average scores of these firms strategic perception are adjacent to each other. In 16 Likert-type scale queries from 0 to 5 the scores do not show "explosive" deviations.

- A noteworthy conclusion of the study is that micro and small enterprises in the service sector of the less developed business ecosystem of the Greek region of Eastern Macedonia and Thrace seem to be heading a clear desire to systematize their strategic perception and implementation. The positive change in the overall average score from 2.4 in the near past to 3.1 today suggests this clear tendency to systematize the 
strategic perception and implementation these firms desire-also combined with the crisis conditions that the Greek economy has been facing over the recent years.

- In particular, the development of the corporate mission from the third question seems to be an aspect of the strategy that hinders this desire since it records the lowest score in the present with 1.43 points. At the other end, it seems that these firms want to use a strategic marketing concept that focuses on ever-larger segments of the market- the 15 th question records the highest score in the present with 3.74 points.

We conclude that there seems to be a significant gap between the prevailing "theory" and "practice" of strategy in the field of micro and small enterprises. The strategic management theory, which describes in paradigmatic terms a model of advanced and flexible entrepreneurship, seems to be inconsistent with the everyday practice of micro and small enterprises and, in particular, those that operate in weaker business ecosystems. However, a contribution of our study lies in the fact that it finds a convergence tendency, even in the context of such a weak and relatively underdeveloped business ecosystem, like that of Eastern Macedonia and Thrace.

In this context, a policy to foster entrepreneurship in weaker business ecosystems could use similar questionnaires in the field, not only based on the respondent's perception, but also by taking into account the perspective of external consultants. Specific mechanisms for enhancing local entrepreneurship could monitor the strategic trends as a whole as well as in specific local firms.

However, this article also has some methodological limitations:

- The sample of 54 enterprises, although specialized in the service sector, is comparatively small and lacks representativeness for the whole region.

- At the same time, this research has a narrow qualitative orientation and does not correlate analytically the quantitative characteristics and performance of the sample enterprises, either overall or individually.

- This research seeks to make a first exploration of the problem, paving the way for future studies on this issue.

Therefore:

- Future studies could deepen and systematize this field research further by taking first a more representative sample of enterprises. This future research could use the strategy perception and implementation index by utilizing more fully financial data in order to identify the correlation between specific strategic practices and financial results of businesses.

- It could create an integrated framework of action research (Coghlan \& Shani, 2017; Eden \& Ackermann, 2018) to develop new methods to enhance strategy planning and implementation for this size and type of firms. 
- Finally, it could expand the study by using the synthesis of strategy, technology, and management (the Stra.Tech.Man approach) by articulating analogous and corresponding technology and management questionnaires and synthesizing upon the results.

\section{Acknowledgment}

The authors thank Dr. Andreas Andrikopoulos, Associate Professor at the Department of Business Administration of the University of the Aegean, for the useful comments during the writing of this manuscript. They also thank the undergraduate students at the Department of Economics of the Democritus University of Thrace Evmorfili Mpairamidou and Kyriakos Grigoriadis for their help in collecting and sorting out the sample.

\section{References}

Abdallah, C., \& Langley, A. (2014). The double edge of ambiguity in strategic planning. Journal of Management Studies, 51(2), 235-264. https://doi.org/10.1111/joms.12002

Abdullah, Z., Shahrina, M. N., \& Abdul Aziz, Y. (2013). Building a unique online corporate identity. Marketing Intelligence \& Planning, 31(5), 451-471. https://doi.org/10.1108/MIP-04-2013-0057

Ackermann, F., \& Eden, C. (2011). Making Strategy: Mapping Out Strategic Success (First edition published 1998). London, UK: SAGE.

Altıok, P. (2011). Applicable vision, mission and the effects of strategic management on crisis resolve. Procedia - Social and Behavioral Sciences, 24, 61-71. https://doi.org/10.1016/j.sbspro.2011.09.057

Analoui, F., \& Karami, A. (2003). Strategic Management in Small and Medium Enterprises. London: Thomson Learning.

Arieli, T. (2019). Intermunicipal cooperation and ethno-social disparity in peripheral regions. Regional Studies, 53(2), 183-194. https://doi.org/10.1080/00343404.2018.1453129

Asheim, B. T., Moodysson, J., \& TÖdtling, F. (2011). Constructing regional advantage: Towards state-of-the-art regional innovation system policies in Europe? European Planning Studies, 19(7), 1133-1139. https://doi.org/10.1080/09654313.2011.573127

Baetz, M. C., \& Bart, C. K. (1996). Developing mission statements which work. Long Range Planning, 29(4), 526-533. https://doi.org/10.1016/0024-6301(96)00044-1

Balkytè, A., \& Tvaronavičienè, M. (2010). Perception of competitiveness in the context of sustainable development: Facets of "sustainable competitiveness." Journal of Business Economics and Management, 11(2), 341-365. https://doi.org/10.3846/jbem.2010.17

Bartkus, B. R., \& Glassman, M. (2008). Do firms practice what they preach? The relationship between mission statements and stakeholder management. Journal of Business Ethics, 83(2), 207-216. https://doi.org/10.1007/s10551-007-9612-0 
Boden, M. (2017). Ris3 implementation in lagging regions: Lessons from Eastern Macedonia and Thrace. European Structural \& Investment Funds Journal, 5(1), 77-83.

Brown, R., \& Mason, C. (2017). Looking inside the spiky bits: A critical review and conceptualisation of entrepreneurial ecosystems. Small Business Economics, 49(1), 11-30. https://doi.org/10.1007/s11187-017-9865-7

Burns, A. C., \& Bush, R. F. (2008). Basic Marketing Research: Using Microsoft Excel data analysis (2nd ed.). Upper Saddle River, N.J: Pearson Prentice Hall.

Burton, F. G., Emett, S. A., Simon, C. A., \& Wood, D. A. (2012). Corporate managers' reliance on internal auditor recommendations. AUDITING: A Journal of Practice \& Theory, 31(2), 151-166. https://doi.org/10.2308/ajpt-10234

Campbell, A., \& Tawadey, K. (1990). Mission and business philosophy: The basis for a committed organization. London: Heinemann.

Coghlan, D., \& Shani, A. B. (2017). Inquiring in the present tense: The dynamic mechanism of action research. Journal of Change Management, 17(2), 121-137.

Dibrell, C., Craig, J. B., \& Neubaum, D. O. (2014). Linking the formal strategic planning process, planning flexibility, and innovativeness to firm performance. Journal of Business Research, 67(9), 2000-2007. https://doi.org/10.1016/j.jbusres.2013.10.011

Eden, C., \& Ackermann, F. (2018). Theory into practice, practice to theory: Action research in method development. European Journal of Operational Research, 271(3), 1145-1155. https://doi.org/10.1016/j.ejor.2018.05.061

Eppler, M. J., \& Platts, K. W. (2009). Visual strategizing: The systematic use of visualization in the strategic-planning process. Long Range Planning, 42(1), 42-74. https://doi.org/10.1016/j.lrp.2008.11.005

Fernández-Serrano, J., \& Romero, I. (2013). Entrepreneurial quality and regional development: Characterizing SME sectors in low income areas. Papers in Regional Science, 92(3), 495-513. https://doi.org/10.1111/j.1435-5957.2012.00421.x

Fitzgerald, C., \& Cunningham, J. A. (2016). Inside the university technology transfer office: Mission statement analysis. The Journal of Technology Transfer, 41(5), 1235-1246. https://doi.org/10.1007/s10961-015-9419-6

Fragidis, G., Koumpis, A., \& Tarabanis, K. (2007). The impact of customer participation on business ecosystems. In L. M. Camarinha-Matos, H. Afsarmanesh, P. Novais, \& C. Analide (Eds.), Establishing the Foundation of Collaborative Networks (pp. 399-406). New York: Springer US. https://doi.org/10.1007/978-0-387-73798-0_42

Gandellini, G., Pezzi, A., \& Venanzi, D. (2012). External and Internal analysis of the environment. In G. Gandellini, A. Pezzi, \& D. Venanzi (Eds.), Strategy for Action - I: The Logic and Context of Strategic Management (pp. 45-84). Dordrecht: Springer. https://doi.org/10.1007/978-88-470-2487-8_2 
González-Dávila, E., Yanes-Estévez, V., María García-Pérez, A., \& Ramón Oreja-Rodríguez, J. (2014). Strategic positioning and strategic types of small firms. Journal of Small Business and Enterprise Development, 21(3), 431-449. https://doi.org/10.1108/JSBED-04-2014-0056

Hamel, G., \& Prahalad, C. K. (1989). Strategic intent. Harvard Business Review, 67(3), 63-76.

Hamel, G., \& Prahalad, C. K. (1994). Competing for the future. Boston, Mass: Harvard Business School Press.

Harrison, R., Scheela, W., Lai, P. C., \& Vivekarajah, S. (2018). Beyond institutional voids and the middle-income trap: The emerging business angel market in Malaysia. Asia Pacific Journal of Management, 35(4), 965-991. https://doi.org/10.1007/s10490-017-9535-y

Hellenic Statistical Authority. (2019, June 12). National Accounts. Retrieved June 12, 2019, from Hellenic Statistical Authority website: http://www.statistics.gr/en/statistics/eco

Hong, P., Hirota, S., Won Park, Y., Kubo, K., \& Miyajima, H. (2010). Corporate mission, corporate policies and business outcomes: Evidence from Japan. Management Decision, 48(7), 1134-1153. https://doi.org/10.1108/00251741011068815

Houston, M. B., Ratneshwar, S., Ricci, L., \& Malter, A. J. (2010). Dynamic strategic goal setting: Theory and initial evidence. In N. K. Malhotra (Ed.), Review of Marketing Research (Vol. 7, pp. 19-62). https://doi.org/10.1108/S1548-6435(2010)0000007006

Huggins, R., \& Thompson, P. (2015). Entrepreneurship, innovation and regional growth: A network theory. Small Business Economics, 45(1), 103-128. https://doi.org/10.1007/s11187-015-9643-3

Iansiti, M., \& Levien, R. (2004). The Keystone Advantage: What the New Dynamics of Business Ecosystems Mean for Strategy, Innovation, and Sustainability. Boston, Mass: Harvard Business School Press.

Ingenhoff, D., \& Fuhrer, T. (2010). Positioning and differentiation by using brand personality attributes: Do mission and vision statements contribute to building a unique corporate identity? Corporate Communications: An International Journal, 15(1), 83-101. https://doi.org/10.1108/13563281011016859

Ismail, N. A., \& Kuivalainen, O. (2015). The effect of internal capabilities and external environment on small- and medium-sized enterprises' international performance and the role of the foreign market scope: The case of the Malaysian halal food industry. Journal of International Entrepreneurship, 13(4), 418-451. https://doi.org/10.1007/s10843-015-0160-x

Johnson, B. (2001). Toward a new classification of nonexperimental quantitative research. Educational Researcher, 30(2), 3-13. https://doi.org/10.3102/0013189X030002003

Kaleta, A., \& Witek-Crabb, A. (2015). Participation in the strategic management process and the expansiveness of the strategy. Argumenta Oeconomica, 1(34), 61-76. https://doi.org/10.15611/aoe.2015.1.02 
Karami, A., \& Taghi Alavi, M. (2009). Managers of small and medium enterprises: Mission statement and enhanced organisational performance. Journal of Management Development, 28(6), 555-562. https://doi.org/10.1108/02621710910959729

Kraus, S., Reiche, B. S., \& Reschke, C. H. (2008). Implications of strategic planning in SMEs for international entrepreneurship research and practice. In M. Terziovski, Energizing Management Through Innovation and Entrepreneurship (pp. 128-145). London: Routledge.

Likert, R. (1932). A technique for the measurement of attitudes. Archives of Psychology, 22(140), 5-55.

Mantere, S., \& Vaara, E. (2008). On the Problem of participation in strategy: A critical discursive perspective. Organization Science, 19(2), 341-358. https://doi.org/10.1287/orsc.1070.0296

Marín, C. A., Stalker, I., \& Mehandjiev, N. (2007). Business ecosystem modelling: combining natural ecosystems and multi-agent systems. In M. Klusch, K. V. Hindriks, M. P. Papazoglou, \& L. Sterling (Eds.), Cooperative Information Agents XI (pp. 181-195). Berlin: Springer. https://doi.org/10.1007/978-3-540-75119-9_13

Marshall, A. (1890). Principles of Economics. London: Macmillan.

Mayer, M., Zbaraszewski, W., Pieńkowski, D., Gach, G., \& Gernert, J. (2019). Cross-border politics and development in the European Union with a focus on tourism. In M. Mayer, W. Zbaraszewski, D. Pieńkowski, G. Gach, \& J. Gernert (Eds.), Cross-Border Tourism in Protected Areas: Potentials, Pitfalls and Perspectives (pp. 65-84). Cham, Switzerland: Springer. https://doi.org/10.1007/978-3-030-05961-3_3

Mazzarol, T. (2003). The Strategic Management of Small Firms: Does the Theory Fit the Practice? (No. DP 0301). Retrieved from Centre for Entrepreneurial Management and Innovation website: www.cemi.com.au

Mia, L., Sands, J., \& Iselin, E. R. (2008). Multi-perspective strategic goal setting, performance reporting and organisational performance. Journal of Applied Accounting Research, 9(2), 76-96. https://doi.org/10.1108/09675420810900766

Miles, R. E., \& Snow, C. C. (1978). Organisational Strategy, Structure and Processes. New York: McGraw-Hill.

Mintzberg, H. (1987). The Strategy concept I: Five Ps for strategy. California Management Review, 30(1), 11-24. https://doi.org/10.2307/41165263

Moore, J. (1993). Predators and prey: A new ecology of competition. Harvard Business Review, 71(3), 75-86.

Moore, J. (1997). The Death of Competition: Leadership and Strategy in the Age of Business Ecosystems (1st paperback ed.). New York, NY: Harper Business.

Moore, J. (2015). Shared Purpose: A Thousand Business Ecosystems, a Connected 
Community, and the Future. (3rd ed.). Concord, Massachusetts: First Ecosystem.

Neergaard, H., \& Ulhøi, J. P. (Eds.). (2007). Handbook of Qualitative Research Methods in Entrepreneurship. Cheltenham, UK; Northampton, MA: Edward Elgar. https://doi.org/10.4337/9781847204387

Peneder, M. (2017). Competitiveness and industrial policy: From rationalities of failure towards the ability to evolve. Cambridge Journal of Economics, 41(3), 829-858. https://doi.org/10.1093/cje/bew025

Peters, T. J., \& Waterman, R. H. (1982). In Search of Excellence: Lessons from America's Best-run Companies. New York: Harper \& Row.

Porter, M. (1990). The competitive advantage of nations. Harvard Business Review: International Business, (March-April $1990 \quad$ Issue), 73-91. https://doi.org/10.1007/978-1-349-11336-1

Porter, M. E. (1980). Competitive strategy: Techniques for analyzing industries and competitors. New York: Free Press.

Porter, M. E. (2000). Locations, clusters, and company strategy. In G. L. Clark, M. S. Gertler, M. Feldman, \& K. Williams, The Oxford Handbook of Economic Geography (pp. 253-274). Oxford; New York: Oxford University Press.

Prahalad, C. K., \& Hamel, G. (1990). Core competence of the corporation. Harvard Business Review, 68(3), 79-91.

Prawitt, D. F., Smith, J. L., \& Wood, D. A. (2009). Internal audit quality and earnings management. The Accounting Review, 84(4), 1255-1280. https://doi.org/10.2308/accr.2009.84.4.1255

Prokkola, E.-K. (2019). Border-regional resilience in EU internal and external border areas in Finland. European Planning Studies, 27(20), 1-20. https://doi.org/10.1080/09654313.2019.1595531

Reyes Avila, F. J., \& Preiss, A. (2015). Strategic management: A survival need for Mexican SMEs. Business Management and Strategy, 6(1), 65-73. https://doi.org/10.5296/bms.v6i1.7481

Sammut-Bonnici, T., Galea, D., \& Cooper, C. L. (2015). PEST analysis. In Wiley Encyclopedia of Management: Vol. $12 \quad$ (140) $\quad$ (p. 1$)$. https://doi.org/10.1002/9781118785317.weom120113

Shields, P. M., \& Rangarajan, N. (2013). A Playbook for Research Methods: Integrating Conceptual Frameworks and Project Management. Stillwater, OK: New Forum Press.

Spigel, B., \& Harrison, R. (2018). Toward a process theory of entrepreneurial ecosystems. Strategic Entrepreneurship Journal, 12(1), 151-168. https://doi.org/10.1002/sej.1268

Spyropoulou, S., Katsikeas, C. S., Skarmeas, D., \& Morgan, N. A. (2018). Strategic goal 
accomplishment in export ventures: The role of capabilities, knowledge, and environment. Journal of the Academy of Marketing Science, 46(1), 109-129. https://doi.org/10.1007/s11747-017-0519-8

Stapenhurst, T. (2009). The Benchmarking Book: A How-to-guide to Best Practice for Managers and Practitioners. Oxford, UK: Routledge. https://doi.org/10.4324/9780080943329

Stebbins, R. A. (2001). Exploratory research in the social sciences. Thousand Oaks, Calif: Sage Publications. https://doi.org/10.4135/9781412984249

Varol, C., \& Soylemez, E. (2019). Socio-spatial network structures in border regions: West and east borders of Turkey. In X. Ye \& X. Liu (Eds.), Cities as Spatial and Social Networks (pp. 207-225). Cham: Springer International Publishing. https://doi.org/10.1007/978-3-319-95351-9_12

Vlados, Ch, Deniozos, N., \& Chatzinikolaou, D. (2018). Towards a new approach of local development under crisis conditions: Empowering the local business ecosystems in Greece, by adopting a new local development policy. International Journal of Regional Development, 5(1), 1-24. https://doi.org/10.5296/ijrd.v5i1.11955

Vlados, Ch. (2004). La Dynamique Du Triangle Stratégie, Technologie Et Management: L'insertion Des Entreprises Grecques Dans La Globalisation (Thèse de doctorat de Sciences Économiques, Université de Paris X-Nanterre). Retrieved from http://www.theses.fr/2004PA100022

Vlados, Ch. (2019). On a correlative and evolutionary SWOT analysis. Journal of Strategy and Management. https://doi.org/10.1108/JSMA-02-2019-0026

Vlados, Ch., \& Chatzinikolaou, D. (2019a). Crisis and entrepreneurship in Greece: Present, past and evolving trends. Presented at the 6th International Conference on Applied Economics "INSTITUTIONS \& THE KNOWLEDGE ECONOMY," Volos, Greece. Retrieved from https://www.researchgate.net/publication/333652675_Crisis_and_entrepreneurship_in_Greec e_Present_past_and_evolving_trends

Vlados, Charis, \& Chatzinikolaou, D. (2019b). Towards a restructuration of the conventional SWOT analysis. Business and Management Studies, 5(2), 76-84. https://doi.org/10.11114/bms.v5i2.4233

Watson, G. H. (2014). Benchmarking in project definition. In N. Balakrishnan, T. Colton, B. Everitt, W. Piegorsch, F. Ruggeri, \& J. L. Teugels (Eds.), Wiley StatsRef: Statistics Reference Online (p. stat04010). Hoboken, NJ: John Wiley \& Sons. https://doi.org/10.1002/9781118445112.stat04010

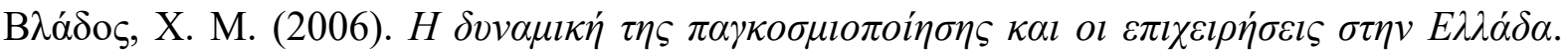

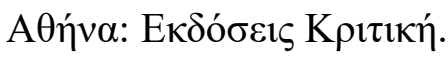




\section{Macrothink Institute $^{\mathrm{TM}}$}

\section{Appendix}

Appendix 1. The Questionnaire

\begin{tabular}{|l|l|}
\hline \multicolumn{2}{|c|}{ COMPANY'S DETAILS } \\
\hline Company's name & \\
\hline $\begin{array}{l}\text { Description/business subject (Greek tax authority } \\
\text { activity code) }\end{array}$ & \\
\hline Headquarters/Branches (address) & \\
\hline Website & \\
\hline Number of employees & \\
\hline Respondent's contact details (telephone and email) & \\
\hline Respondent's name-surname & \\
\hline Job position of the respondent within the company & \\
\hline Founding year of the company & \\
\hline University's research team at no cost & \\
\hline
\end{tabular}




\section{How does your company change within the crisis?}

*Select the corresponding number in the box/cell of the table and comment

\section{S1: Strategic goals}

The principal strategic goal of the organization is:

\begin{tabular}{|c|c|c|c|c|c|}
\hline \multicolumn{6}{|c|}{ TODAY: } \\
\hline 0 & 1 & 2 & 3 & 4 & 5 \\
\hline \multicolumn{6}{|c|}{ IN THE PAST: } \\
\hline 0 & 1 & 2 & 3 & 4 & 5 \\
\hline $\begin{array}{l}\text { There is no } \\
\text { principal } \\
\text { strategic goal }\end{array}$ & $\begin{array}{l}\text { The short-term } \\
\text { profitability and/or } \\
\text { the reduction of the } \\
\text { immediate } \\
\text { uncertainty }\end{array}$ & $\begin{array}{c}\text { Between } 1 \text { \& } \\
3\end{array}$ & $\begin{array}{l}\text { The steady } \\
\text { expansion and } \\
\text { the long-term } \\
\text { perspective }\end{array}$ & $\begin{array}{c}\text { Between } 3 \& \\
5\end{array}$ & $\begin{array}{c}\text { The rapid } \\
\text { adaptation to } \\
\text { change while } \\
\text { retaining a } \\
\text { long-term strategic } \\
\text { premise }\end{array}$ \\
\hline
\end{tabular}

Do you have a written strategic plan or an integrated business plan?

- Yes

- No

Where would you like to be today instead, and why? 


\section{S2: General strategic conception}

Which one of the following generic descriptions do you think best suits your business strategy?

\begin{tabular}{|c|c|c|c|c|c|}
\hline \multicolumn{6}{|c|}{ TODAY: } \\
\hline 0 & 1 & 2 & 3 & 4 & 5 \\
\hline \multicolumn{6}{|c|}{ IN THE PAST: } \\
\hline 0 & 1 & 2 & 3 & 4 & 5 \\
\hline $\begin{array}{l}\text { There is no } \\
\text { general } \\
\text { strategic logic }\end{array}$ & $\begin{array}{c}\text { "Free and } \\
\text { instinctive": } \\
\text { without } \\
\text { bureaucracy and } \\
\text { limitations }\end{array}$ & $\begin{array}{l}\text { "Sure": with an } \\
\text { awareness of the } \\
\text { limitations and } \\
\text { without unnecessary } \\
\text { "analyses and } \\
\text { strategies" }\end{array}$ & $\begin{array}{c}\text { "Stable": } \\
\text { systematic and } \\
\text { planned }\end{array}$ & $\begin{array}{c}\text { "Open": } \\
\text { systematic but } \\
\text { with } \\
\text { considerable } \\
\text { scope for } \\
\text { assimilation of } \\
\text { the new }\end{array}$ & $\begin{array}{c}\text { "Flexible": } \\
\text { systematically } \\
\text { oriented towards } \\
\text { change }\end{array}$ \\
\hline
\end{tabular}

Where would you like to be today instead, and why?

\section{S3: Mission statement within the organization}

If there is a written corporate mission statement in your business, who has/have been involved enough in its formulation and development?
A. CEO-President
B. Top management and business consultants/external partners
C. Shareholders
D. Mid-level executives
E. All the human resources of the organization 


\begin{tabular}{|c|c|c|c|c|c|}
\hline \multicolumn{6}{|c|}{ TODAY: } \\
\hline 0 & 1 & 2 & 3 & 4 & 5 \\
\hline \multicolumn{6}{|c|}{ IN THE PAST: } \\
\hline 0 & 1 & 2 & 3 & 4 & 5 \\
\hline $\begin{array}{l}\text { There is no } \\
\text { written } \\
\text { corporate } \\
\text { mission }\end{array}$ & $\mathrm{A}$ & $A+B$ & $A+B+C$ & $A+B+C+D$ & $\begin{array}{c}\mathrm{A}+\mathrm{B}+\mathrm{C}+\mathrm{D} \\
+\mathrm{E}\end{array}$ \\
\hline
\end{tabular}

Where would you like to be today instead, and why?

\section{S4: External participation in the mission statement}

To what extent have you recognized and expressed the business goals in the corporate mission statement based on regular contact and collaboration with your customers, partners, suppliers, and the broader society in which you operate?

\begin{tabular}{|c|c|c|c|c|c|}
\hline \multicolumn{7}{|c|}{ TODAY: } \\
\hline 0 & 1 & 2 & 3 & 4 & 5 \\
\hline & & & & & \\
\hline \multicolumn{7}{|l|}{ IN THE PAST: } \\
\hline 0 & 1 & 2 & 3 & 4 & 5 \\
\hline & & & & & \\
\hline
\end{tabular}

Where would you like to be today instead, and why? 


\section{S5: PEST analysis}

To what extent does the strategy gather, take into account, and valorizes systematically and continuously the data concerning the evolution of the general extra-sectoral trends and factors (political, economic, legal, social, technological, environmental, demographic) as necessary components of its strategic decisions?

\begin{tabular}{|c|c|c|c|c|c|}
\hline \multicolumn{7}{|c|}{ TODAY: } \\
\hline 0 & 1 & 2 & 3 & 4 & 5 \\
\hline & & & & & \\
\hline \multicolumn{7}{|c|}{ IN THE PAST: } \\
\hline 0 & 1 & 2 & 3 & 4 & 5 \\
\hline & & & & & \\
\hline
\end{tabular}

Where would you like to be today instead, and why?

\section{S6: Five Forces analysis}

To what extent does your organization collect and monitor data about the dynamics of its direct competitive environment and relating to its:

- Customers

- Suppliers

- Competitors

- Potential new competitors

- Networks of trade intermediates and partners

- Substitute products

- Complementary products 


\begin{tabular}{|c|c|c|c|c|c|}
\hline \multicolumn{7}{|c|}{ TODAY: } \\
\hline 0 & 1 & 2 & 3 & 4 & 5 \\
\hline & & & & & \\
\hline \multicolumn{7}{|c|}{ IN THE PAST: } \\
\hline 0 & 1 & 2 & 3 & 4 & 5 \\
\hline & & & & & \\
\hline
\end{tabular}

Where would you like to be today instead, and why?

\section{S7: Competitiveness and Porter's diamond}

To what extent your firm's competitiveness (defined as to distribute profitably in the market products and services in conditions of international competition) is favored, positively influenced, and enhanced:

If the productive fabric of other firms - both related and complementary - that surround it at its local operating level is sophisticated?

\begin{tabular}{|l|l|l|l|l|l|l|l|l|l|l|l|}
\hline \multicolumn{9}{|c|}{ TODAY: } & \multicolumn{7}{c|}{ IN THE PAST: } \\
\hline 0 & 1 & 2 & 3 & 4 & 5 & 0 & 1 & 2 & 3 & 4 & 5 \\
\hline & & & & & & & & & & & \\
\hline
\end{tabular}

If the competition from rival firms operating at your local level is intense and of high quality?

\begin{tabular}{|c|c|c|c|c|c|c|c|c|c|c|c|}
\hline \multicolumn{6}{|c|}{ TODAY: } & \multicolumn{6}{|c|}{ IN THE PAST: } \\
\hline 0 & 1 & 2 & 3 & 4 & 5 & 0 & 1 & 2 & 3 & 4 & 5 \\
\hline \multicolumn{12}{|c|}{ If your input markets and suppliers are sophisticated at your local operating level? } \\
\hline \multicolumn{6}{|c|}{ TODAY: } & \multicolumn{6}{|c|}{ IN THE PAST: } \\
\hline 0 & 1 & 2 & 3 & 4 & 5 & 0 & 1 & 2 & 3 & 4 & 5 \\
\hline & & & & & & & & & & & \\
\hline
\end{tabular}

If your output markets and customers are sophisticated and demanding at your local operating level?

\begin{tabular}{|c|c|c|c|c|c|c|c|c|c|c|c|}
\hline \multicolumn{9}{|c|}{ TODAY: } & \multicolumn{7}{c|}{ IN THE PAST: } \\
\hline 0 & 1 & 2 & 3 & 4 & 5 & 0 & 1 & 2 & 3 & 4 & 5 \\
\hline & & & & & & & & & & & \\
\hline
\end{tabular}

If there are systematic and developed interactions in terms of technology diffusion and assimilation at the local operating level of the firm (e.g., local technological partnerships, existence of technological culture and assimilation of the know-how by the human resources locally)? 


\begin{tabular}{|c|c|c|c|c|c|c|c|c|c|c|c|}
\hline \multicolumn{6}{|c|}{ TODAY: } & \multicolumn{6}{|c|}{ IN THE PAST: } \\
\hline 0 & 1 & 2 & 3 & 4 & 5 & 0 & 1 & 2 & 3 & 4 & 5 \\
\hline & & & & & & & & & & & \\
\hline \multicolumn{11}{|c|}{ If your external local operating environment manages over time to maintain and develop } & \\
\hline \multicolumn{12}{|c|}{ a) Its local, natural, and environmental resources, } \\
\hline \multicolumn{12}{|c|}{ b) Its local conditions of social development, and } \\
\hline \multicolumn{12}{|c|}{ nological potential elements of evolution? } \\
\hline \multicolumn{6}{|c|}{ TODAY: } & \multicolumn{6}{|c|}{ IN THE PAST: } \\
\hline 0 & 1 & 2 & 3 & 4 & 5 & 0 & 1 & 2 & 3 & 4 & 5 \\
\hline \multicolumn{12}{|c|}{$\begin{array}{l}\text { If the state-social intervention institutions manage to respond to the specificities of the local } \\
\text { reality within which you operate? }\end{array}$} \\
\hline \multicolumn{6}{|c|}{ TODAY: } & \multicolumn{6}{|c|}{ IN THE PAST: } \\
\hline 0 & 1 & 2 & 3 & 4 & 5 & 0 & 1 & 2 & 3 & 4 & 5 \\
\hline & & & & & & & & & & & \\
\hline \multirow{2}{*}{\multicolumn{12}{|c|}{$\begin{array}{l}\text { If your business strategy manages to adapt appropriately to the above structural balances at you } \\
\text { local operating level? }\end{array}$}} \\
\hline & & & & & & & & & & & \\
\hline \multicolumn{6}{|c|}{ TODAY: } & \multicolumn{6}{|c|}{ IN THE PAST: } \\
\hline 0 & 1 & 2 & 3 & 4 & 5 & 0 & 1 & 2 & 3 & 4 & 5 \\
\hline \multicolumn{12}{|c|}{ AVERAGE } \\
\hline \multicolumn{6}{|c|}{ TODAY: } & \multicolumn{6}{|c|}{ IN THE PAST: } \\
\hline
\end{tabular}

\section{Where would you like to be today instead, and why?}

\section{S8: Strategic benchmarking}

To what extent does your business strategy capture data systematically and continuously of other "successful strategies" within and outside your industry (external benchmarking)?

\begin{tabular}{|l|l|l|l|l|c|}
\hline \multicolumn{7}{|c|}{ TODAY: } \\
\hline 0 & 1 & 2 & 3 & 4 & 5 \\
\hline & & & & & \\
\hline \multicolumn{7}{|c|}{ IN THE PAST: } \\
\hline 0 & 1 & 2 & 3 & 4 & 5 \\
\hline & & & & & \\
\hline
\end{tabular}


* Where would you like to be today instead, and why?

\section{S9: Internal audit}

To what extent does your business strategy have and systematically activate mechanisms to monitor and evaluate the functional transformations that take place within its partial business functions (sales department, staff department, financial administration department, etc.) and present its conclusions in the form of regular internal audit reports?

\begin{tabular}{|l|l|l|l|l|c|}
\hline \multicolumn{7}{|c|}{ TODAY: } \\
\hline 0 & 1 & 2 & 3 & 4 & 5 \\
\hline & & & & & \\
\hline \multicolumn{7}{|c|}{ IN THE PAST: } \\
\hline 0 & 1 & 2 & 3 & 4 & 5 \\
\hline & & & & & \\
\hline
\end{tabular}

Where would you like to be today instead, and why?

\section{S10: Mintzberg's five Ps of strategy}

Which do you think is the degree of practical use and activation of the following dimensions in your business strategy?

Strategy as a plan: It manages to be the preplanned scheme that helps achieve specific goals that have been set.

\begin{tabular}{|l|l|l|l|l|l|l|l|l|l|l|c|}
\hline \multicolumn{9}{|c|}{ TODAY: } & \multicolumn{7}{c|}{ IN THE PAST: } \\
\hline 0 & 1 & 2 & 3 & 4 & 5 & 0 & 1 & 2 & 3 & 4 & 5 \\
\hline & & & & & & & & & & & \\
\hline
\end{tabular}

Strategy as a ploy: It manages to be the system of maneuvers that help you win the battles of competition.

\begin{tabular}{|c|c|c|c|c|c|c|c|c|c|c|c|}
\hline \multicolumn{9}{|c|}{ TODAY: } & \multicolumn{7}{c|}{ IN THE PAST: } \\
\hline 0 & 1 & 2 & 3 & 4 & 5 & 0 & 1 & 2 & 3 & 4 & 5 \\
\hline & & & & & & & & & & & \\
\hline
\end{tabular}


Strategy as a pattern: It manages to be the elaborated business behavior model that ensures consistency and efficiency, especially in the implementation phase.

\begin{tabular}{|c|c|c|c|c|c|c|c|c|c|c|c|}
\hline \multicolumn{9}{|c|}{ TODAY: } & \multicolumn{7}{c|}{ IN THE PAST: } \\
\hline 0 & 1 & 2 & 3 & 4 & 5 & 0 & 1 & 2 & 3 & 4 & 5 \\
\hline & & & & & & & & & & & \\
\hline
\end{tabular}

Strategy as a position: It manages to be the general framework of the company's integration into its environment without reference to "tactical" details.

\begin{tabular}{|l|l|l|l|l|l|l|l|l|l|l|c|}
\hline \multicolumn{9}{|c|}{ TODAY: } & \multicolumn{7}{c|}{ IN THE PAST: } \\
\hline 0 & 1 & 2 & 3 & 4 & 5 & 0 & 1 & 2 & 3 & 4 & 5 \\
\hline & & & & & & & & & & & \\
\hline
\end{tabular}

Strategy as a perspective: It manages to be the coherent space for expressing the ideology and aspirations that exist within the firm and the mentality of the individuals operating within it.

\begin{tabular}{|c|c|c|c|c|c|c|c|c|c|c|c|}
\hline \multicolumn{6}{|c|}{ TODAY: } & \multicolumn{6}{|c|}{ IN THE PAST: } \\
\hline 0 & 1 & 2 & 3 & 4 & 5 & 0 & 1 & 2 & 3 & 4 & 5 \\
\hline \multicolumn{12}{|c|}{ AVERAGE } \\
\hline \multicolumn{6}{|c|}{ TODAY: } & \multicolumn{6}{|c|}{ IN THE PAST: } \\
\hline
\end{tabular}

Where would you like to be today instead, and why?

\section{S11: Strategic intent}

From the three approaches, which combination does your business strategy assimilate in practice?

A. The approach of the environmental definition of industrial organization:

The firm's strategy is tailored to the specific features of its business environment.

B. The approach of the resources and competencies of the firm:

The strategy is based on what the business can do better than its competitors can.

C. Strategic intent approach:

The firm's strategy is not enough to adapt to the "rules of the game" and environmental conditions, but envisions the future ahead of its competitors and attempts with strategic interventions to lead to victory by "changing the rules of the game." 


\begin{tabular}{|c|c|c|c|c|c|}
\hline \multicolumn{6}{|c|}{ TODAY: } \\
\hline 0 & 1 & 2 & 3 & 4 & 5 \\
\hline & A & $\mathrm{B}$ & $A+B$ & $\mathrm{~A}+\mathrm{C}$ or $\mathrm{B}+\mathrm{C}$ & $A+B+C$ \\
\hline \multicolumn{6}{|c|}{ IN THE PAST: } \\
\hline 0 & 1 & 2 & 3 & 4 & 5 \\
\hline & $\mathrm{A}$ & $\mathrm{B}$ & $A+B$ & $\mathrm{~A}+\mathrm{C}$ or $\mathrm{B}+\mathrm{C}$ & $A+B+C$ \\
\hline
\end{tabular}

Where would you like to be today instead, and why?

\section{S12: Level of strategic abstraction—mission, vision, philosophy}

Although the following dimensions are complementary, where do you think your business already has high-level strategic processing?

A. Mission statement

o Outlines the primary purpose of the firm

o Determines the relationship of the firm with other organizations

o Sets specific goals

B. Vision

o Carves the shape of the firm in the future

o Sets general goals

$\circ$ Leads the strategy and mission

C. Philosophy

o Incorporates organizational values, defines general principles and ethical behavior in the operation of the organization

o Determines the nature of the relationships with the parties that the organization deals with

$\circ$ Defines the style of management 


\begin{tabular}{|c|c|c|c|c|c|}
\hline \multicolumn{6}{|c|}{ TODAY: } \\
\hline 0 & 1 & 2 & 3 & 4 & 5 \\
\hline & A & B & A + B & B + C & A + B + C \\
\hline 0 & 1 & IN THE PAST: & 4 & 5 \\
\hline & A & B & A + B & B + C & A + B + C \\
\hline
\end{tabular}

Where would you like to be today instead, and why?

\section{S13: Use of strategic planning}

Evaluate the practical use and contribution of the following strategic dimensions to the actual operation of your organization.

The strategy sets out directions: If the mission and/or vision determine where the organization seeks to be in the future, then the answer to how it will arrive there lies in its strategy.

\begin{tabular}{|c|c|c|c|c|c|c|c|c|c|c|c|}
\hline \multicolumn{9}{|c|}{ TODAY: } & \multicolumn{7}{c|}{ IN THE PAST: } \\
\hline 0 & 1 & 2 & 3 & 4 & 5 & 0 & 1 & 2 & 3 & 4 & 5 \\
\hline & & & & & & & & & & & \\
\hline
\end{tabular}

The strategy supports uniform decision-making and coordinates the activity: In the absence of

some stability and particular orientation, it is tough to examine the consequences of each operational option and to make the best decision in a way that is in line with the overall effort.

\begin{tabular}{|c|c|c|c|c|c|c|c|c|c|c|c|}
\hline \multicolumn{9}{|c|}{ TODAY: } & \multicolumn{7}{c|}{ IN THE PAST: } \\
\hline 0 & 1 & 2 & 3 & 4 & 5 & 0 & 1 & 2 & 3 & 4 & 5 \\
\hline & & & & & & & & & & & \\
\hline
\end{tabular}

The strategy defines the company itself and its position about the competition: The strategy is the "personality" of the organization, and it answers the question "what kind of business we are" in the external and internal organizational environment.

\begin{tabular}{|c|c|c|c|c|c|c|c|c|c|c|c|}
\hline \multicolumn{9}{|c|}{ TODAY: } & \multicolumn{7}{c|}{ IN THE PAST: } \\
\hline 0 & 1 & 2 & 3 & 4 & 5 & 0 & 1 & 2 & 3 & 4 & 5 \\
\hline & & & & & & & & & & & \\
\hline
\end{tabular}

The strategy reduces uncertainty: Under the prism of a clear business strategy, it is easier to take advantage of an opportunity and protect yourself from a threat.

\begin{tabular}{|c|c|c|c|c|c|c|c|c|c|c|c|}
\hline \multicolumn{9}{|c|}{ TODAY: } & \multicolumn{7}{c|}{ IN THE PAST: } \\
\hline 0 & 1 & 2 & 3 & 4 & 5 & 0 & 1 & 2 & 3 & 4 & 5 \\
\hline & & & & & & & & & & & \\
\hline
\end{tabular}


The strategy confers a sustainable competitive advantage: It allows businesses to achieve a permanent connection between the external environment and their specific internal capabilities.

\begin{tabular}{|c|c|c|c|c|c|c|c|c|c|c|c|}
\hline \multicolumn{1}{|c|}{ TODAY: } & \multicolumn{1}{c|}{ IN THE PAST: } \\
\hline 0 & 1 & 2 & 3 & 4 & 5 & 0 & 1 & 2 & 3 & 4 & 5 \\
\hline & & & & & & & & & & & \\
\hline \multicolumn{3}{|c|}{ AVERAGE } \\
\hline
\end{tabular}

Where would you like to be today instead, and why?

\section{S14: Participation in strategy}

The strategic success of your organization is mainly based on:

\begin{tabular}{|c|c|c|c|c|c|}
\hline \multicolumn{6}{|c|}{ TODAY: } \\
\hline 0 & 1 & 2 & 3 & 4 & 5 \\
\hline & 1 & 2 & 3 & 4 & 5 \\
\hline 0 & IN THE PAST: & Between 3 \& 5 & $\begin{array}{c}\text { Team effort and } \\
\text { collaboration } \\
\text { and creativity of } \\
\text { all within the } \\
\text { owner's instinct } \\
\text { and imagination }\end{array}$ \\
\hline & Thetwization \\
\hline
\end{tabular}

Where would you like to be today instead, and why?

\section{S15: Marketing perspective in terms of "Porter's generic strategies"}

The prevailing strategy perception in terms of marketing applied by the firm fits more in the following statement: 


\begin{tabular}{|c|c|c|c|c|c|}
\hline \multicolumn{6}{|c|}{ TODAY: } \\
\hline 0 & 1 & 2 & 3 & 4 & 5 \\
\hline \multicolumn{6}{|c|}{ IN THE PAST: } \\
\hline 0 & 1 & 2 & 3 & 4 & 5 \\
\hline $\begin{array}{c}\text { Selling } \\
\text { whatever is } \\
\text { sellable }\end{array}$ & $\begin{array}{l}\text { Production: } \\
\text { "The product } \\
\text { produced in } \\
\text { large quantities } \\
\text { that has low } \\
\text { cost and stable } \\
\text { quality sells" }\end{array}$ & $\begin{array}{l}\text { Product: } \\
\text { "Good } \\
\text { quality } \\
\text { product } \\
\text { sells" }\end{array}$ & $\begin{array}{c}\text { Sale: } \\
\text { "The good product } \\
\text { accompanied by a } \\
\text { systematic and } \\
\text { aggressive } \\
\text { promotional effort } \\
\text { sells" }\end{array}$ & $\begin{array}{l}\text { Market: } \\
\text { "The product } \\
\text { made } \\
\text { according to } \\
\text { the customer's } \\
\text { wants sells" }\end{array}$ & $\begin{array}{l}\text { Society: } \\
\text { "The product that } \\
\text { meets the customer's } \\
\text { immediate wants but } \\
\text { also the customer's } \\
\text { and the entire } \\
\text { society's long-term } \\
\text { interest sells and will } \\
\text { sell in the future" }\end{array}$ \\
\hline
\end{tabular}

\section{Where would you like to be today instead, and why?}

\section{S16: In search of excellence}

To what extent does your strategy trigger and make use of the following principles, viewing them as foundations in your business operations?

Bias for action: Fast and creative assimilation of environmental changes, not just "analysis for analysis."

\begin{tabular}{|c|c|c|c|c|c|c|c|c|c|c|c|}
\hline \multicolumn{1}{|c|}{ TODAY: } & \multicolumn{1}{c|}{ IN THE PAST: } \\
\hline 0 & 1 & 2 & 3 & 4 & 5 & 0 & 1 & 2 & 3 & 4 & 5 \\
\hline & & & & & & & & & & & \\
\hline \\
Close to the customer: The customer is our partner and defines our quality. \\
\hline \multicolumn{10}{|c|}{ TODAY: } \\
\hline 0 & 1 & 2 & 3 & 4 & 5 & 0 & 1 & 2 & 3 & 4 & 5 \\
\hline & & & & & & & & & & & IN THE PAST: \\
\hline
\end{tabular}

Autonomy and entrepreneurship: We encourage innovators and risk-takers, we are not afraid of mistakes, but, on the contrary, we know how to use them.

\begin{tabular}{|c|c|c|c|c|c|c|c|c|c|c|c|}
\hline \multicolumn{9}{|c|}{ TODAY: } & \multicolumn{7}{c|}{ IN THE PAST: } \\
\hline 0 & 1 & 2 & 3 & 4 & 5 & 0 & 1 & 2 & 3 & 4 & 5 \\
\hline & & & & & & & & & & & \\
\hline
\end{tabular}


Productivity through people: The human factor is ultimately the source of the firm's creativity and success.

\begin{tabular}{|l|l|l|l|l|l|l|l|l|l|l|l|}
\hline \multicolumn{9}{|c|}{ TODAY: } & \multicolumn{7}{c|}{ IN THE PAST: } \\
\hline 0 & 1 & 2 & 3 & 4 & 5 & 0 & 1 & 2 & 3 & 4 & 5 \\
\hline & & & & & & & & & & & \\
\hline
\end{tabular}

Hands-on, value-driven: The purpose, the values and/or the firm's mission prevail, the means change with flexibility.

\begin{tabular}{|c|c|c|c|c|c|c|c|c|c|c|c|}
\hline \multicolumn{9}{|c|}{ TODAY: } & \multicolumn{7}{c|}{ IN THE PAST: } \\
\hline 0 & 1 & 2 & 3 & 4 & 5 & 0 & 1 & 2 & 3 & 4 & 5 \\
\hline & & & & & & & & & & & \\
\hline
\end{tabular}

Stick to the knitting: Knowledge of the specific product and its production and our accumulated experience is critical. The occupation with many different objects and occasional moves is disorienting and proving to be harmful.

\begin{tabular}{|c|c|c|c|c|c|c|c|c|c|c|c|}
\hline \multicolumn{6}{|c|}{ TODAY: } & \multicolumn{6}{|c|}{ IN THE PAST: } \\
\hline 0 & 1 & 2 & 3 & 4 & 5 & 0 & 1 & 2 & 3 & 4 & 5 \\
\hline \multicolumn{12}{|c|}{$\begin{array}{l}\text { Simple form, lean staff: Simple structure, few hierarchical levels, fast and efficient } \\
\text { communication. }\end{array}$} \\
\hline \multicolumn{6}{|c|}{ TODAY: } & \multicolumn{6}{|c|}{ IN THE PAST: } \\
\hline 0 & 1 & 2 & 3 & 4 & 5 & 0 & 1 & 2 & 3 & 4 & 5 \\
\hline & & & & & & & & & & & \\
\hline
\end{tabular}

Simultaneous loose-tight properties: Exploiting both centralization in some processes and widespread decentralization in others.

\begin{tabular}{|c|c|c|c|c|c|c|c|c|c|c|c|}
\hline \multicolumn{6}{|c|}{ TODAY: } & \multicolumn{6}{|c|}{ IN THE PAST: } \\
\hline 0 & 1 & 2 & 3 & 4 & 5 & 0 & 1 & 2 & 3 & 4 & 5 \\
\hline \multicolumn{12}{|c|}{ AVERAGE } \\
\hline \multicolumn{6}{|c|}{ TODAY: } & \multicolumn{6}{|c|}{ IN THE PAST: } \\
\hline
\end{tabular}

Where would you like to be today instead, and why? 
Final strategic results

\begin{tabular}{|c|c|c|}
\hline & TODAY & $\begin{array}{c}\text { IN THE } \\
\text { PAST }\end{array}$ \\
\hline S1: Strategic goals & & \\
\hline S2: General strategic conception & & \\
\hline S3: Mission statement within the organization & & \\
\hline S4: External participation in the mission statement & & \\
\hline S5: PEST analysis & & \\
\hline S6: Five Forces analysis & & \\
\hline S8: Strategic benchmarking & & \\
\hline S9: Internal audit & & \\
\hline S10: Mintzberg's five Ps of strategy & & \\
\hline S11: Strategic intent & & \\
\hline p12: Level of strategic abstraction-mission, vision, & & \\
\hline philosophy & & \\
\hline S14: Participation in strategy & & \\
\hline S15: Marketing perspective in terms of "Porter's generic & & \\
\hline strategies" & & \\
\hline S16: In search of excellence & & \\
\hline Average total & & \\
\hline
\end{tabular}

Average score results:

- 0 to 2: Strong evidence that your organization is of "monadocentric" type

- 3 to 4: Strong evidence that your organization is of "massive" type

- 5: Strong evidence that your organization is of "flexible" type

\section{Copyright}

Copyright for this article is retained by the author(s), with first publication rights granted to the journal.

This is an open-access article distributed under the terms and conditions of the Creative Commons Attribution license (http://creativecommons.org/licenses/by/4.0/). 